\title{
Biochemical and elemental composition of the offshore-cultivated oysters Ostrea edulis and Crassostrea gigas
}

\author{
B. Pogoda a,b,*, B.H. Buck ${ }^{\text {b,c }}$, R. Saborowski ${ }^{\text {b }}$, W. Hagen ${ }^{\text {a }}$ \\ a University of Bremen, Bremen Marine Ecology (BreMarE), P.O. Box 330440, 28359 Bremen, Germany \\ ${ }^{\mathrm{b}}$ Alfred Wegener Institute for Polar and Marine Research (AWI), Am Handelshafen 12, 27550 Bremerhaven, Germany \\ c Bremerhaven University of Applied Sciences, Applied Marine Biology, An der Karlstadt 8, 27568 Bremerhaven, Germany
}

\section{A R T I C L E I N F O}

\section{Article history:}

Received 27 March 2012

Received in revised form 21 February 2013

Accepted 22 February 2013

Available online 13 March 2013

\section{Keywords:}

Glycogen

Lipid

NMI fatty acid

Offshore aquaculture

Multi-use

IMTA candidates

\begin{abstract}
A B S T R A C T
Offshore production of seafood is a promising approach to evade numerous specific problems related to aquaculture activities in coastal areas. The aim of this study was to investigate the biological performance of oysters, typical near-shore organisms and potent aquaculture candidates, in an offshore environment. Juveniles of two oyster species, Ostrea edulis and Crassostrea gigas, were transferred to an offshore cultivation site in the German North Sea and cultivated from April to October 2007. Samples were taken every six to eight weeks to determine biochemical and elemental compositions: total glycogen (TG), total protein, total lipid (TL) as well as lipid classes, fatty acids (FA) and the yields and ratios of carbon, hydrogen and nitrogen. Results show an increase in glycogen from spring to early summer for both species, which is related to high food abundance during spring phytoplankton bloom. During summer, glycogen storage revealed clear differences between 0 . edulis and C. gigas attributing to the reproductive activity of $C$. gigas but not 0 . edulis. TG contents ranged between $6 \%$ and $23 \%$ dry mass (DM) in 0 . edulis and between $5 \%$ and $16 \%$ DM in C. gigas. Total protein contents did not show significant seasonal variations and ranged between $34 \%$ and $41 \%$ DM in both species. TL contents increased during summer, although the increase was clearly more pronounced in C. gigas, followed by a decrease in both species in autumn. TL levels ranged between $7 \%$ and $14 \%$ DM in both species. Phospholipids and triacylglycerols were the main lipid classes in both oyster species, followed by sterols. FA compositions resembled those of near-shore-grown oysters. We conclude that offshorecultivated oysters exhibit a natural biological performance, emphasizing their suitability as offshore aquaculture candidates.
\end{abstract}

(C) 2013 Elsevier B.V. All rights reserved.

\section{Introduction}

Marine aquaculture activities cumulate along coastal areas. These activities, however, often cause serious and unresolved problems like pollution and coastal destruction mainly associated with intensive culture methods (McElwee, 1998). Environmental stress as well as stakeholder conflicts in ocean use (Buck et al., 2004; Wirtz et al., 2002) constrain a further expansion of this important sector for food production (FAO, 2009). Accordingly, efforts are required to establish alternative, sustainable, and environmentally friendly cultivation methods. A promising but technically ambitious approach is an extensive cultivation of extractive culture species in the open ocean (Buck, 2002; Buck et al., 2004, 2008; Delmendo, 1998; Ferreira et al., 2009; Krause et al., 2003; Pogoda et al., 2011; Troell et al., 2009). Open-ocean or offshore aquaculture transfers aquaculture operations from sheltered near-shore areas to more exposed environments. Structures are exposed to high wave action and strong currents (Pogoda et al., 2011; Ryan, 2005). However,

\footnotetext{
* Corresponding author at: University of Bremen, Bremen Marine Ecology (BreMarE), P.O. Box 330440, 28359 Bremen, Germany. Tel.: + 49421 21863037; fax: + 4942121863055 .

E-mail address: bernadette.pogoda@uni-bremen.de (B. Pogoda).
}

excellent water quality is a great advantage over coastal areas, which is crucial for the performance and health of cultured species (BSH, 2006; Takayanagi, 1998).

Filter-feeding shellfish species such as oysters are suitable candidates for extensive cultivation, as they do not require supplemental feeding (Garen et al., 2004; Gibbs, 2004). Moreover, they can even improve water quality as essential bio-extractive organisms (Ferreira et al., 2009; Rose et al., 2010). Oysters, furthermore, represent high-value products. Compared to other shellfish species, they yield high prices on the market (FAO, 2011; Troell et al., 2009) and are therefore ideal candidates for cost-intensive offshore aquaculture.

Several studies were carried out on seasonal changes of the biochemical composition of oysters (Abad et al., 1995; Costil et al., 2005; Dridi et al., 2007; Li et al., 2009; Linehan et al., 1999; Robert et al., 1993; Ruíz et al., 1992; Soletchnik et al., 2006). However, no information is available about the biological performance and fitness of oysters grown under offshore farming conditions. Therefore, the present study aims at assessing and comparing the performance of two species of oysters, the European flat oyster (Ostrea edulis) and the Pacific oyster (Crassostrea gigas), from a biochemical and ecophysiological point of view. Both species were simultaneously cultivated in an experimental offshore culture 
system in the North Sea (Pogoda et al., 2011). The oysters were raised over an entire growing season and analyzed for their carbon, hydrogen, and nitrogen contents, total lipid (TL) contents, lipid class and fatty acid (FA) compositions as well as glycogen and protein contents. The data were evaluated with regard to the biological performance of $O$. edulis and C. gigas in the North Sea and their suitability for offshore aquaculture.

\section{Material and methods}

\subsection{Study site and experimental design}

The European oyster (O. edulis) and the Pacific oyster (C. gigas) were cultivated at the test site Nordergründe (NG) in the German Bight $\left(53^{\circ}\right.$ $51,0^{\circ} \mathrm{N} ; 008^{\circ} 04,0^{\circ} \mathrm{E}$, Fig. 1 ). This site, located 9 nautical miles off the coast, was previously established as a test site for offshore aquaculture activities (Buck, 2007) and fulfills the offshore-criteria in terms of a high-energy environment according to Ryan (2005). Detailed information about the seasonal changes of abiotic and biotic parameters, including temperature, salinity, chlorophyll, phaeophytin, particulate organic carbon (POC), particulate organic nitrogen (PON) and nitrate/nitrite, as well as comparisons with other inshore and near-shore sites are provided by Pogoda et al., 2011 and Brenner, 2009.

In temperate regions both oyster species show an inactive period during winter but start feeding in spring (Løfstedt, 2010; Matthiessen, 2001). Therefore, this study was conducted over one complete growing season from April to October 2007. Juvenile oysters were obtained from commercial hatcheries. Bonamia-free oyster spat of 0 . edulis was bought from Bømlo Skell A. Musling (Norway) and C. gigas spat from Guernsey Seafarms (UK). 600 individuals of either species were transferred to the test site in April 2007 and reared in small oyster lanterns, specifically developed for offshore aquaculture experiments. In the beginning of the experiment average shell lengths were $38.5 \pm 0.5 \mathrm{~mm}$ (O. edulis) and $24.7 \pm 0.5 \mathrm{~mm}$ (C. gigas) (Pogoda et al., 2011). Lanterns were permanently submerged and independent from tidal water level changes. Samples (80 individuals of each species) were collected by SCUBA-divers in April, June, August and October. Details of the sampling procedure and maintenance are described by Pogoda et al. (2011).

\subsection{Environmental parameters}

Data for temperature, salinity, chlorophyll (a, b, $c_{1,2}$, phaeophytin) and carotenoids, nitrate and nitrite $\left(\mathrm{NO}_{\mathrm{X}}\right), \mathrm{POC}$, and PON as well as phosphate and ammonium concentrations were obtained from the Marine Environment Reporting System (BSH, 2009) and Brenner (2009). These data are presented in detail by Pogoda et al. (2011).

\subsection{Biochemical analysis}

The oysters were opened carefully and the entire soft body was removed from the shell. The soft body was not separated into organs or body parts to avoid leakage of inter- and intracellular fluids (Whyte et al., 1990). After freezing at $-80^{\circ} \mathrm{C}$ and lyophilization (Leybold-Heraeus Lyovac GT2) for $48 \mathrm{~h}$ oyster dry mass (DM) was determined using a Sartorius micro-balance (R200D).

Lipid extraction and gravimetric determination of TL were performed after the method of Folch et al. (1957) modified by Hagen (2000). The samples were first homogenized in dichloromethane:methanol $(2: 1 / \mathrm{v}$ : $\mathrm{v}$, Braun Biotech International, Potter S) and then treated with an ultrasonic cell disruptor (Bandelin electronic, UW 2070). The extracts were washed with aqueous $\mathrm{KCl}$ solution $(0.88 \%)$ to remove proteinous compounds.

Lipid classes were separated and analyzed by high-performance thinlayer chromatography (HPTLC) flame ionization detection (TLC-FID) with an Iatroscan Laboratories model Mk-5 TLC/FID analyzer (Fraser et al., 1985). Samples were run in triplicate. Calibration was affected with single compound standards.

FA were analyzed after Kattner and Fricke (1986). Subsamples (500 $\mu \mathrm{g}$ ) of the TL extracts were hydrolyzed and FA converted to methyl ester derivatives (FAMEs). The conversion was affected in $1 \mathrm{ml}$ methanol containing $3 \%$ concentrated sulfuric acid and $250 \mu \mathrm{l}$ hexane at $80{ }^{\circ} \mathrm{C}$ for $4 \mathrm{~h}$. $2 \mathrm{ml}$ of aqua bidest. was added to the reaction mixture after cooling and FAMEs were extracted three times with $1 \mathrm{ml}$ hexane. Separation of FA was carried out with a gas chromatograph (HP 6890A), which was equipped with a DB-FFAP column (30 m length, $0.249 \mathrm{~mm}$ diameter, $0.25 \mu \mathrm{m}$ film thickness). The carrier gas was helium and the device operated with a temperature program. FAMEs

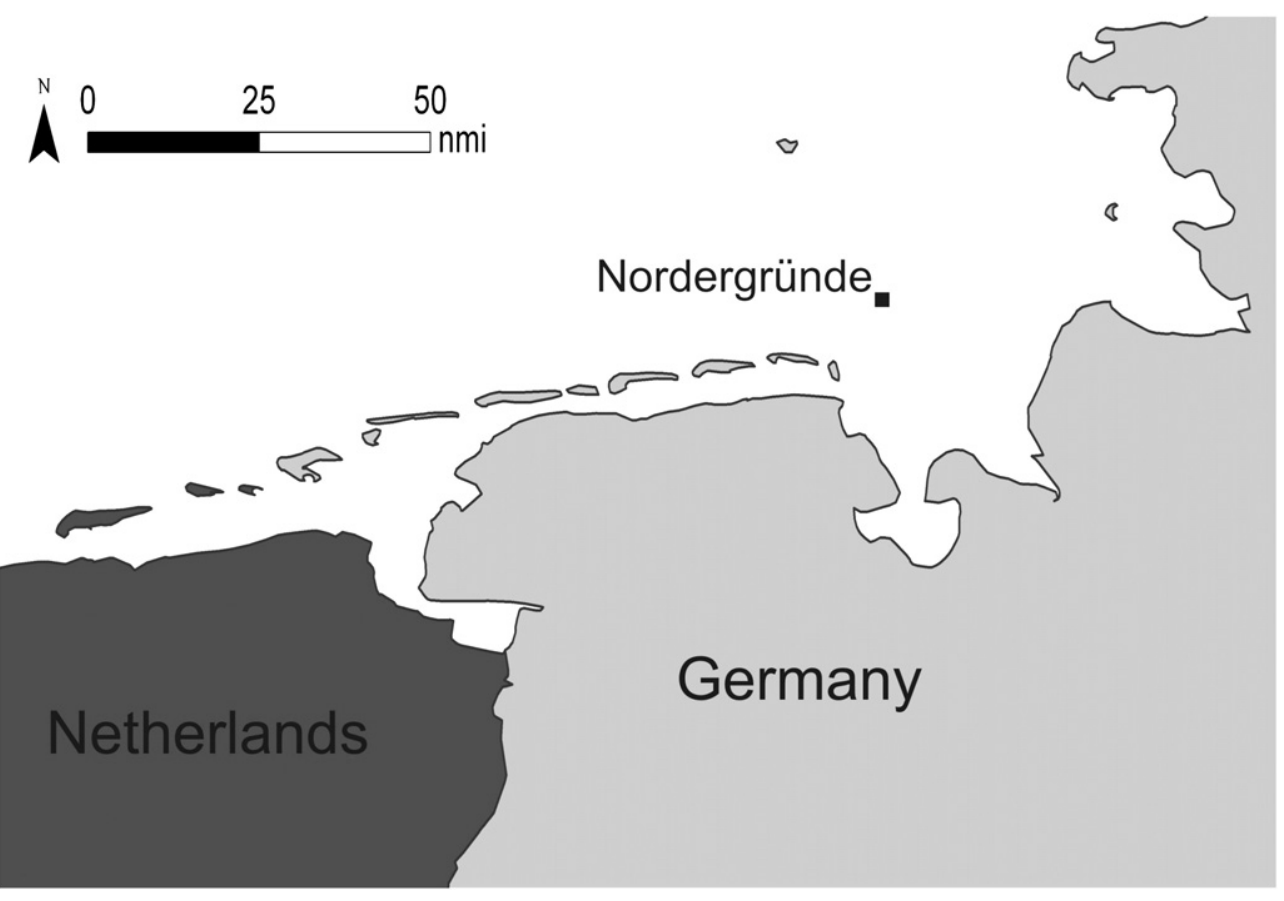

Fig. 1. Map of the German Bight showing the test site Nordergründe (NG) in the North Sea. 
and fatty alcohols were detected by flame ionization and identified by comparing the retention times with those of known standards (Marinol, Solvay Pharmaceuticals).

For carbohydrate (glycogen and glucose) and protein determination freeze-dried soft tissue of oysters was ground into a fine powder under liquid nitrogen. Glycogen and glucose were determined according to Keppler and Decker (1984) and Kunst et al. (1984) as modified for use in microplates by Saborowski and Buchholz (1996). Frozen and lyophilized tissue powder (20-30 mg) was transferred into reaction cups, placed on ice, and homogenized in $1 \mathrm{ml}$ aqua bidest. by ultrasonication (Branson Sonifier B15). After homogenization extracts were heated for $10 \mathrm{~min}$ at $95{ }^{\circ} \mathrm{C}$ (Eppendorf Thermomixer Comfort) to destroy glycogen-degrading enzymes. Subsamples were taken for glycogen and glucose determination. The subsamples for glycogen determination were incubated for $2 \mathrm{~h}$ at $40{ }^{\circ} \mathrm{C}$ in $500 \mu \mathrm{l} 0.1$ acetate buffer ( $\mathrm{pH} 4.8$ ) with $20 \mu \mathrm{l}$ amyloglucosidase to hydrolyze glycogen to glucose (Boehringer). After centrifugation $\left(10 \mathrm{~min}, 15000 \mathrm{~g}, 4{ }^{\circ} \mathrm{C}\right)$, supernatants of both subsamples were used for the determination of glucose performed with a commercial glucose UV test kit (Boehringer, No. 10716251035). $10 \mu \mathrm{l}$ of sample and $300 \mu \mathrm{l}$ of buffer solution 1 (test kit) were transferred into microplates. Optical density of samples was read at $340 \mathrm{~nm}$ in a microplate reader (Thermo Scientific, Multiscan FC, Software Scan it 2.5.1). These values served as background values in the subsequent calculation of the glucose content. Hexokinase suspension (dilution 1:5 in aqua bidest.) was added to each sample and the plate was incubated for $30 \mathrm{~min}$ at $25{ }^{\circ} \mathrm{C}$ before the optical density was read again at $340 \mathrm{~nm}$. All samples were run in triplicate and standards in parallel yielding per well 0, 2.5, 5.0, 7.5 and $10.0 \mu \mathrm{g}$ of glucose (component of the test kit).

Protein content was analyzed according to Lowry et al. (1951). Frozen tissue powder $(400-500 \mu \mathrm{g})$ was homogenized on ice in $1 \mathrm{ml}$ aqua bidest. by ultrasonication (Branson Sonifier B15). The dye reaction was performed with the commercial test kit DC Protein Assay Kit II (BIORAD, 500-0112). Bovine serum albumin served as standard.

Carbon $(\mathrm{C})$, nitrogen $(\mathrm{N})$ and hydrogen $(\mathrm{H})$ were measured in an elemental analyzer (VarioMicroCube, Elementar), using sulfanilamid as standard.

\subsection{Statistical analysis}

Means, standard deviations, standard errors of the mean (mean \pm $\mathrm{SE}$ ) and confidence intervals (mean $\pm \mathrm{CI}$ ) of biochemical and elemental compositions were calculated and tested for normal distribution with MS-Excel software. Differences in TL, glycogen and protein as well as lipid class and FA compositions between seasons and species were tested with the Student's $t$-test (MS-Excel software) and considered to be significant when $p<0.05$. Additionally, two-way ANOVA was performed using GraphPad Prism 5.0.4.

\section{Results}

\subsection{Elemental composition}

Carbon, the main elemental component of the soft body, increased in both oyster species during summer and decreased slightly in autumn (Table 1). Mean carbon values of 0 . edulis increased from $29.1 \pm 1.6 \%$ in April to $37.6 \pm 0.5 \%$ in June and to $39.4 \pm 0.7 \%$ in August. In October they dropped to $31.4 \pm 1.2 \%$. Mean carbon values of $C$. gigas increased from $26.9 \pm 0.7 \%$ in April to $38.8 \pm 0.7 \%$ in June. The values stayed constant until August ( $38.0 \pm 1.3 \%$ ) and dropped to $34.9 \pm 1.6 \%$ in October. Nitrogen contents of 0 . edulis remained at a constant level of $7.5 \%$ in spring and summer but slightly rose to $9.9 \pm 0.9 \%$ in autumn. $C$. gigas showed a continuous increase in nitrogen over the cultivation period. It rose from $7.1 \pm 0.2 \%$ in April to $8.7 \pm 0.2 \%$ in June to $9.0 \pm 0.3 \%$ in August and to $13.8 \pm 2.4 \%$ in October
(Table 1). The share of hydrogen remained constant at around 5\% for both oyster species (Table 1 ).

Resulting $\mathrm{C} / \mathrm{N}$ ratios of 0 . edulis and $\mathrm{C}$. gigas are shown in Fig. 2. In $O$. edulis it increased from April (4.0) to August (5.2) but significantly dropped (3.3) in October $(p<0.05)$. $\mathrm{C} / \mathrm{N}$ ratios of $C$. gigas started at 3.8 in April and increased to 4.4 in June followed by a slight decrease to 4.2 in August. Thereafter, it dropped significantly to 2.5 in October $(p<0.05)$.

\subsection{Biochemical composition}

\subsubsection{Total lipids}

Lipid levels of the European oyster 0. edulis ranged between $6.9 \pm$ $0.5 \% \mathrm{DM}$ in spring and a maximum of $9.4 \pm 1.3 \% \mathrm{DM}$ in early summer (Fig. 3A). These values showed no significant differences during the growing season. Lipid contents of the Pacific oyster $C$. gigas were slightly higher than those of 0 . edulis. These increased from $8.0 \pm 0.8 \% \mathrm{DM}$ in spring to $11.3 \pm 1.1 \% \mathrm{DM}$ in early summer and reached a maximum of $14.4 \pm 1.4 \% \mathrm{DM}$ in late summer (Fig. 3B). The differences over the season were statistically significant $(p<0.0001)$ (Table 2$)$.

\subsection{Lipid class composition}

In both species, triacylglycerols (TAG) served as main storage lipids throughout the growing season. The relative amount of TAG in 0 . edulis ranged between $18.5 \pm 6.3 \% \mathrm{TL}$ in spring and $40.1 \pm 3.1 \% \mathrm{TL}$ in autumn. In $C$. gigas lipid contents ranged between $3.3 \pm 2.8 \% \mathrm{TL}$ in spring and $42.2 \pm 6.6 \% \mathrm{TL}$ in late summer (Fig. 3A, B; Table 2). Due to the applied analytical method wax esters (WE) and sterol esters (SE) could not be separated and are combined in one group. Fatty alcohols, which usually derive from WE, appeared regularly. These are, however, no typical compounds in oysters. The relative amounts of the WE/SE were similar in both species and ranged between $5.4 \pm 2.5 \% \mathrm{TL}$ and $7.9 \pm 1.2 \% \mathrm{TL}$ in 0 . edulis and $5.9 \pm 3.2 \% \mathrm{TL}$ and $9.5 \pm 1.2 \% \mathrm{TL}$ in $C$. gigas. Sterols showed highest values in spring (O. edulis $17.8 \pm 2.6 \%$ $\mathrm{TL}, \mathrm{C}$. gigas $22.7 \pm 1.5 \% \mathrm{TL}$ ) and lower but constant levels of around $10 \%$ during the rest of the growing season. Only in C. gigas an increase to $15.4 \pm 2.1 \% \mathrm{TL}$ was observed in late autumn. Phospholipids (PL) formed the main polar lipid component in both species and ranged between 40 and $60 \%$ of TL (Table 2). The low share of free FA confirms the high quality of the samples (no autolysis).

\subsection{Fatty acid composition}

Seasonal and growth induced changes in the FA compositions are shown in Table 3. The typical membrane components 16:0, 20:5( $n-3)$ and 22:6(n-3) predominated the FA compositions of both species ( $>12 \%$ each). Fatty alcohols were present as 14:0 and 16:0 alcohols. In the neutral lipid (NL) fraction 15 important FA (maximum values $\geq 2 \%$ of total FA (TFA) were identified. Two C22 dienoic acids

\section{Table 1}

Seasonal variation of elemental composition of Ostrea edulis and Crassostrea gigas at the offshore cultivation site Nordergründe ( $\mathrm{n}=20$ per species and sampling date). C: carbohydrates, H: hydrogen, N: nitrogen.

\begin{tabular}{lllll}
\hline Ostrea edulis & \% & \% & \% & $\mathrm{C} / \mathrm{N}$ \\
\hline April & $29.1 \pm 1.6$ & $7.2 \pm 0.5$ & $4.9 \pm 0.3$ & 4.0 \\
June & $37.6 \pm 0.5$ & $7.9 \pm 0.4$ & $6.1 \pm 0.1$ & 4.8 \\
August & $39.4 \pm 0.7$ & $7.6 \pm 0.3$ & $6.1 \pm 0.1$ & 5.2 \\
October & $31.4 \pm 1.2$ & $9.9 \pm 0.9$ & $5.1 \pm 0.2$ & 3.2 \\
& & & & \\
Crassostrea gigas & & & & \\
April & $26.9 \pm 0.7$ & $7.1 \pm 0.2$ & $4.8 \pm 0.2$ & 3.8 \\
June & $38.8 \pm 0.7$ & $8.7 \pm 0.2$ & $6.3 \pm 0.1$ & 4.4 \\
August & $38.0 \pm 1.3$ & $9.0 \pm 0.3$ & $5.9 \pm 0.2$ & 4.2 \\
October & $34.9 \pm 1.6$ & $13.8 \pm 2.4$ & $5.7 \pm 0.2$ & 2.5 \\
\hline
\end{tabular}




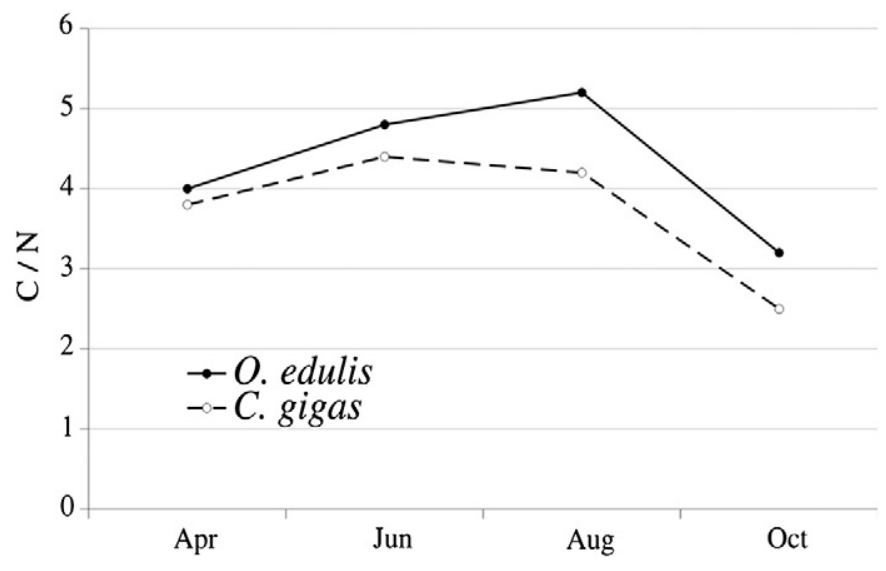

Fig. 2. Seasonal variation of $\mathrm{C} / \mathrm{N}$ ratio in soft tissue of $O$. edulis and $C$. gigas.

appeared: $22: 2 \mathrm{i}$ and $22: 2 \mathrm{j}$, which were identified by mass spectrometry as $22: 2 \Delta 7,13$ and $22: 2 \Delta 7,15$, respectively.

\subsection{Total glycogen}

Glycogen levels of the European oyster showed a different pattern than those of the Pacific oyster (Fig. 3C,D). In O. edulis total glycogen (TG) increased from $6.6 \pm 2.3 \% \mathrm{DM}$ in April to $21.1 \pm 1.5 \% \mathrm{DM}$ in June to $23.2 \pm 1.3 \%$ DM in August, followed by a decrease to $9.9 \pm 2.3 \% \mathrm{DM}$ in October. In C. gigas TG increases from $4.8 \pm 1.0 \% \mathrm{DM}$ in April to $16.5 \pm 1.5 \% \mathrm{DM}$ in June. In August glycogen levels dropped below the spring value $(4.2 \pm 1.4 \% \mathrm{DM})$ but increased again in October (7.2 \pm $2.2 \% \mathrm{DM})$.

\subsection{Total protein}

Protein contents of the European oyster were, after April, slightly lower than those of the Pacific oyster (Fig. 3C, D). In O. edulis total protein showed a small increase from April $(35.6 \pm 1.3 \% \mathrm{DM})$ to June
$(38.9 \pm 0.7 \% \mathrm{DM})$ and a subsequent slight decrease in August and October $(35.7 \pm 1.2 \%$ and $35.0 \pm 0.7 \% \mathrm{DM})$. Pacific oysters showed an increase of total protein from April $(33.4 \pm 1.3 \% \mathrm{DM})$ to June $(40.5 \pm 0.7 \% \mathrm{DM})$ and similar to 0 . edulis a slight decrease in August and October ( $36.8 \pm 0.6 \%$ and $35.5 \pm 0.7 \% \mathrm{DM})$.

\section{Discussion}

The biochemical and elemental compositions of $O$. edulis and $C$. gigas during one growing season were analyzed to investigate the nutritional condition of these species under offshore aquaculture conditions. Accumulation and depletion of metabolic energy reserves primarily depend on food quantity and quality, environmental effects on metabolic processes, and reproductive activities (Beninger and Lucas, 1984; Ruíz et al., 1992; Whyte et al., 1990). A previous study already described successful growth performances for offshore-cultivated European and Pacific oysters, as individuals of both species significantly increased in shell length and DM (Pogoda et al., 2011). The present study focused on seasonal dynamics of the major energy storage products, namely carbohydrates, proteins and lipids, on the compositions of lipid classes and FA as well as on carbon and nitrogen.

Lipids are the most efficient energy sources. They provide much more metabolic energy than the same amount of carbohydrates (glycogen) or proteins. Besides lipids, glycogen is used as energy store, which due to hydrolysis results in a ten times higher mass to reach the same energy yield (Schmidt-Nielsen, 1999). Nevertheless, for some groups of benthic animals, including oysters, glycogen is a preferred form of energy reserve, as it has two major advantages: 1) glycogen catabolism is fast providing instant energy; 2) glycogen catabolism can be performed under hypoxic or anoxic conditions. This is particularly important, when oysters keep their shells closed for longer periods (Hummel et al., 1989; Whyte et al., 1990).

The type of energy deposition preferred by European and Pacific oysters is, however, still controversially discussed. Starvation experiments showed that juvenile $O$. edulis and $C$. gigas follow different strategies of energy storage and utilization (Child and Laing, 1998). The European oyster was found to preferably rely on lipids, while the Pacific oyster
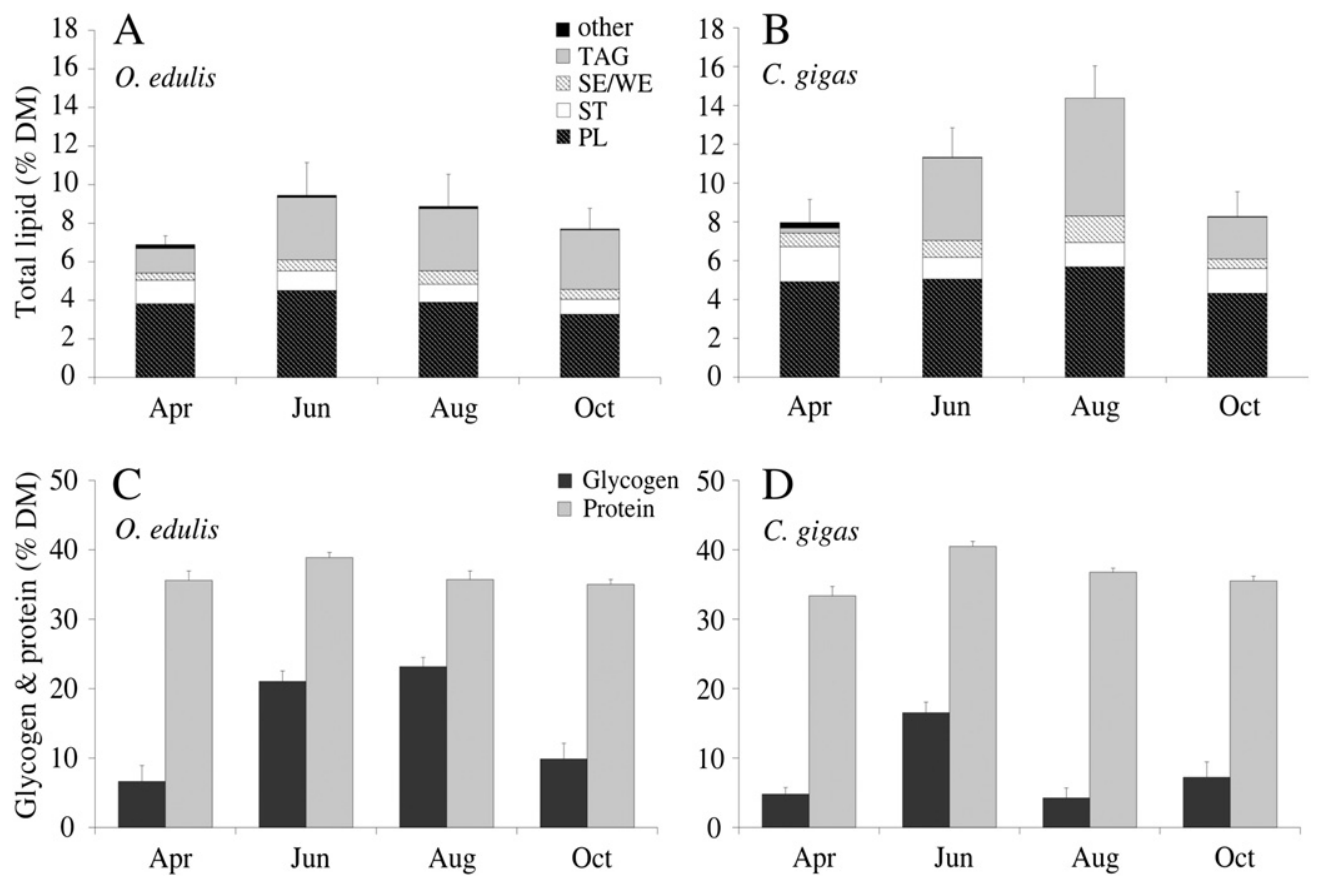

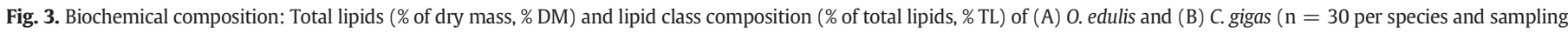

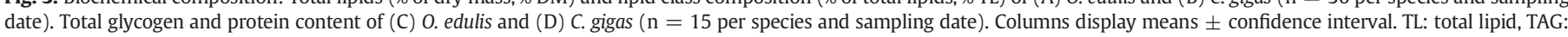
triacylglycerols, SE/WE: sterol esters/wax esters, ST: sterols, PL: phospholipids. 
Table 2

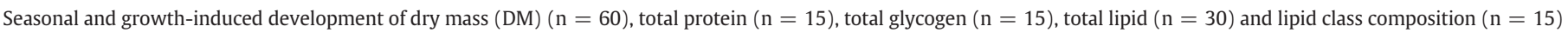

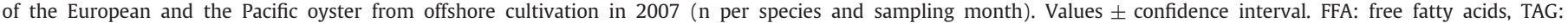
triacylglycerols, SE/WE: sterol esters/wax esters, ST: sterols, PL: phospholipids, (\%TL): \% of total lipids.

\begin{tabular}{|c|c|c|c|c|c|c|c|c|}
\hline & \multicolumn{4}{|l|}{ Ostrea edulis } & \multicolumn{4}{|c|}{ Crassostrea gigas } \\
\hline & Apr & Jun & Aug & Oct & Apr & Jun & Aug & Oct \\
\hline Dry mass (mg) & $134 \pm 16$ & $455 \pm 41$ & $619 \pm 65$ & $879 \pm 107$ & $54 \pm 3$ & $374 \pm 43$ & $390 \pm 43$ & $434 \pm 44$ \\
\hline Total protein (\% DM) & $35.6 \pm 1.3$ & $38.9 \pm 0.7$ & $35.7 \pm 1.2$ & $35.0 \pm 0.7$ & $33.4 \pm 1.3$ & $40.5 \pm 0.7$ & $36.8 \pm 0.6$ & $35.5 \pm 0.7$ \\
\hline Total glycogen (\% DM) & $6.6 \pm 2.5$ & $21.1 \pm 1.7$ & $23.2 \pm 1.5$ & $9.9 \pm 2.2$ & $4.6 \pm 1.0$ & $16.5 \pm 1.7$ & $4.2 \pm 1.6$ & $7.2 \pm 2.4$ \\
\hline Total lipid (\% DM) & $6.9 \pm 0.5$ & $9.4 \pm 1.3$ & $8.9 \pm 1.3$ & $7.7 \pm 0.8$ & $8.0 \pm 0.8$ & $11.3 \pm 1.1$ & $14.4 \pm 1.4$ & $8.3 \pm 0.9$ \\
\hline FFA $(\% \mathrm{TL})$ & $2.8 \pm 1.6$ & $0.8 \pm 1.4$ & $0.9 \pm 1.0$ & $0.5 \pm 0.5$ & $3.5 \pm 2.8$ & $0.2 \pm 0.7$ & 0 & $0.4 \pm 1.1$ \\
\hline TAG (\% TL) & $18.5 \pm 6.3$ & $34.4 \pm 4.1$ & $36.6 \pm 3.2$ & $40.1 \pm 3.1$ & $3.3 \pm 2.8$ & $37.6 \pm 7.0$ & $42.2 \pm 6.6$ & $26.1 \pm 4.9$ \\
\hline SE/WEa (\% TL) & $5.4 \pm 2.3$ & $6.2 \pm 1.5$ & $7.9 \pm 1.2$ & $6.7 \pm 1.1$ & $8.7 \pm 2.9$ & $7.7 \pm 1.1$ & $9.5 \pm 1.2$ & $5.9 \pm 3.2$ \\
\hline $\mathrm{ST}(\% \mathrm{TL})$ & $17.8 \pm 2.6$ & $10.8 \pm 1.8$ & $10.6 \pm 1.2$ & $10.1 \pm 1.0$ & $22.7 \pm 1.5$ & $9.9 \pm 2.7$ & $8.7 \pm 2.6$ & $15.4 \pm 2.1$ \\
\hline $\mathrm{PL}(\% \mathrm{TL})$ & $55.5 \pm 6.2$ & $47.8 \pm 3.9$ & $44.0 \pm 3.7$ & $42.6 \pm 2.7$ & $61.8 \pm 5.0$ & $44.6 \pm 5.7$ & $39.6 \pm 4.9$ & $52.2 \pm 5.5$ \\
\hline $\mathrm{PL} / \mathrm{NL}$ & 3.0 & 1.4 & 1.2 & 1.1 & 18.7 & 1.2 & 0.9 & 2.0 \\
\hline
\end{tabular}

a Group of sterol esters and wax esters: no separation with applied method.

was assumed to utilize proteins based on insignificant reductions in lipid and carbohydrate contents. Other authors identified lipids (Robinson, 1992; Ruíz et al., 1992) or glycogen (e.g. Holland and Hannant, 1974; Whyte et al., 1990) as the main energy reserve in juvenile and adult European and Pacific oysters: e.g. in O. edulis glycogen peaked in summer and decreased again in winter. Our study on offshore-cultivated 0 . edulis and $C$. gigas revealed similar seasonal glycogen dynamics with a substantial increase from spring to summer and a decrease in autumn. Variations in the lipid and protein contents were much lower. Accordingly, these data support the hypothesis that both species utilize primarily glycogen as an important energy store during the seasonal cycle.

However, more detailed data analyses revealed distinct differences in lipid and glycogen deposition between both species. $C$. gigas exhibited a significantly stronger lipid accumulation until autumn $(p<0.001)$ as compared to 0 . edulis, while glycogen dropped drastically after accumulation during spring and early summer. Overall, the Pacific oyster showed a more pronounced energy deposition, but in autumn lipid and glycogen reserves were depleted to similar levels as those of the European oyster. Energy utilization in $C$. gigas coincided with reduced shell growth and a decrease in DM (Pogoda et al., 2011). This may be explained by reproductive effort, as during summer $C$. gigas $>40 \mathrm{~mm}$ starts to invest energy in gonad maturation (Costil et al., 2005; Royer et al., 2008). The simultaneous glycogen decrease and lipid increase may indicate the conversion of carbohydrates into lipids during ontogenesis (De la Parra et al., 2005; Robinson, 1992; Whyte et al., 1990), as lipid contents of oyster eggs are directly related to survival rates of the lecithotrophic embryonic stages and veliger larvae (Gallager and Mann, 1986). In contrast, O. edulis does not reproduce in its first year after settlement (Walne, 1974; Wilson and Simons, 1985; Newkirk et al., 1995). Accordingly, data on growth performance (Pogoda et al., 2011) and biochemical composition did not indicate any reproductive activities. $O$. edulis of the same size and age as $C$. gigas continued to accumulate glycogen until late summer and lipid levels remained relatively constant.

Thus, for both species glycogen seems to be an important energy store during periods of high food availability, as it was mainly accumulated during the phytoplankton bloom in spring. However, glycogen accumulation continued in 0 . edulis, while in $C$. gigas carbohydrates were eventually converted to lipids and fuelled reproductive processes.

The elemental composition ( $\mathrm{C}, \mathrm{N}$ ) of an organism basically reflects growth and nutritional status (Postel et al., 2000). It gives some hints on physiological condition and indicates shifts in the occurrence of the main organic components, expressed as the ratio between proteins and lipids + carbohydrates in animal tissue (Bayne, 2009). The dominance of lipids and carbohydrates is indicated by a C:N ratio beyond 2.9 (Postel et al., 2000). Increasing $\mathrm{C} / \mathrm{N}$ values from 4.0 to 5.2 confirm the observed accumulation of carbohydrates in 0 . edulis. Interestingly,

Table 3

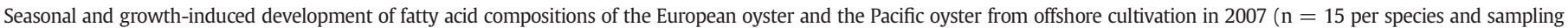
month). TFA: total fatty acids, TFAlc: total fatty alcohols.

\begin{tabular}{|c|c|c|c|c|c|c|c|c|c|}
\hline & & \multicolumn{4}{|l|}{ Ostrea edulis } & \multicolumn{4}{|c|}{ Crassostrea gigas } \\
\hline & & Apr & Jun & Aug & Oct & Apr & Jun & Aug & Oct \\
\hline \multicolumn{10}{|c|}{ Fatty acids (\%TFA $\pm S D)$} \\
\hline $14: 0$ & & $2.0 \pm 0.4$ & $4.1 \pm 0.6$ & $3.7 \pm 0.3$ & $3.7 \pm 0.2$ & $1.3 \pm 0.4$ & $5.0 \pm 1.1$ & $6.2 \pm 2.7$ & $2.1 \pm 0.8$ \\
\hline $16: 0$ & & $18.9 \pm 2.2$ & $22.5 \pm 3.1$ & $21.7 \pm 1.4$ & $21.0 \pm 0.5$ & $19.1 \pm 1.2$ & $20.5 \pm 2.0$ & $24.6 \pm 3.9$ & $23.5 \pm 1.7$ \\
\hline $16: 1(n-7)$ & & $1.5 \pm 0.2$ & $2.6 \pm 0.4$ & $2.4 \pm 0.3$ & $2.4 \pm 0.2$ & $1.9 \pm 0.5$ & $3.3 \pm 1.4$ & $5.2 \pm 1.2$ & $1.6 \pm 0.6$ \\
\hline $17: 0$ & & $2.3 \pm 0.3$ & $1.8 \pm 0.4$ & $1.6 \pm 0.2$ & $1.4 \pm 0.1$ & $1.9 \pm 0.3$ & $1.0 \pm 0.1$ & $1.3 \pm 0.3$ & $1.9 \pm 0.5$ \\
\hline 17:1 & & $2.5 \pm 2.0$ & $1.0 \pm 0.9$ & $1.3 \pm 1.4$ & $1.2 \pm 1.6$ & $4.1 \pm 1.2$ & $0.5 \pm 0.8$ & $0.5 \pm 0.6$ & $3.0 \pm 2.8$ \\
\hline 18:0 & & $5.6 \pm 0.6$ & $5.4 \pm 1.1$ & $3.9 \pm 2.1$ & $4.8 \pm 0.3$ & 0 & $3.8 \pm 0.4$ & $2.2 \pm 1.9$ & $1.9 \pm 2.5$ \\
\hline $18: 1(n-7)$ & & $1.7 \pm 0.3$ & $2.9 \pm 0.6$ & $2.1 \pm 0.3$ & $2.2 \pm 0.3$ & $3.9 \pm 0.4$ & $5.4 \pm 0.5$ & $4.7 \pm 0.5$ & $4.4 \pm 0.5$ \\
\hline $18: 1(n-9)$ & & $3.0 \pm 0.2$ & $2.0 \pm 0.4$ & $2.3 \pm 0.2$ & $2.3 \pm 0.2$ & $2.1 \pm 0.3$ & $2.0 \pm 0.2$ & $1.9 \pm 0.4$ & $1.1 \pm 0.3$ \\
\hline $18: 4(n-3)$ & & $1.6 \pm 0.3$ & $1.7 \pm 1.1$ & $1.5 \pm 0.8$ & $1.9 \pm 0.1$ & 0 & $2.3 \pm 0.3$ & $1.3 \pm 1.0$ & $0.7 \pm 1.0$ \\
\hline $20: 1(n-11)$ & & $1.4 \pm 0.2$ & $0.5 \pm 0.2$ & $0.6 \pm 0.1$ & $0.5 \pm 0.1$ & $2.9 \pm 0.3$ & $0.8 \pm 0.3$ & $0.7 \pm 0.4$ & $1.8 \pm 0.5$ \\
\hline $20: 1(n-9)$ & & $1.4 \pm 0.2$ & $1.4 \pm 0.1$ & $1.0 \pm 0.1$ & $1.0 \pm 0.1$ & $2.1 \pm 0.4$ & $1.4 \pm 0.2$ & $1.3 \pm 0.2$ & $1.9 \pm 0.1$ \\
\hline $20: 1(n-7)$ & & $3.9 \pm 0.2$ & $3.8 \pm 1.7$ & $3.4 \pm 1.5$ & $3.9 \pm 0.3$ & $2.1 \pm 0.4$ & $3.6 \pm 0.6$ & $1.9 \pm 1.3$ & $1.9 \pm 1.6$ \\
\hline $20: 4(n-6)$ & & $3.9 \pm 0.5$ & $2.4 \pm 0.3$ & $2.2 \pm 0.3$ & $2.0 \pm 0.2$ & $4.3 \pm 0.6$ & $2.3 \pm 0.3$ & $2.0 \pm 0.8$ & $3.6 \pm 0.9$ \\
\hline $20: 5(n-3)$ & & $12.5 \pm 0.9$ & $18.0 \pm 2.6$ & $19.5 \pm 1.1$ & $19.9 \pm 0.8$ & $19.5 \pm 1.6$ & $22.5 \pm 1.2$ & $19.1 \pm 1.8$ & $16.4 \pm 1.8$ \\
\hline $22: 2(n-x) i$ & $22: 2 \Delta 7,13$ & $1.3 \pm 0.3$ & $0.5 \pm 0.2$ & $0.7 \pm 0.1$ & $0.6 \pm 0.1$ & $2.1 \pm 0.4$ & $0.6 \pm 0.2$ & $0.5 \pm 0.1$ & $0.9 \pm 0.3$ \\
\hline $22: 2(n-x) j$ & $22: 2 \Delta 7,15$ & $4.9 \pm 0.9$ & $4.0 \pm 0.6$ & $3.9 \pm 0.5$ & $3.4 \pm 0.3$ & $5.6 \pm 0.5$ & $3.3 \pm 0.4$ & $3.8 \pm 0.6$ & $5.8 \pm 1.4$ \\
\hline $22: 5(n-3)$ & & $1.6 \pm 0.1$ & $1.2 \pm 0.1$ & $1.2 \pm 0.1$ & $1.1 \pm 0.1$ & $2.1 \pm 0.2$ & $1.3 \pm 0.1$ & $1.3 \pm 0.3$ & $1.5 \pm 0.3$ \\
\hline $22: 6(n-3)$ & & $23.7 \pm 1.3$ & $18.8 \pm 2.0$ & $21.7 \pm 1.7$ & $21.9 \pm 1.2$ & $19.3 \pm 1.2$ & $15.9 \pm 2.2$ & $15.6 \pm 5.6$ & $21.3 \pm 2.2$ \\
\hline \multicolumn{10}{|c|}{ Fatty alcohols (\%TFAlc $\pm S D)$} \\
\hline $14: 0$ & & $18.1 \pm 17.6$ & $17.1 \pm 15.5$ & $6.7 \pm 9.9$ & $5.5 \pm 12.6$ & $23.4 \pm 11.9$ & 0 & $18.1 \pm 15.0$ & 13. $9 \pm 11.4$ \\
\hline $16: 0$ & & $81.9 \pm 17.6$ & $82.9 \pm 15.8$ & $83.3 \pm 29.4$ & $94.5 \pm 12.6$ & $76.6 \pm 12.6$ & $40.0 \pm 49.0$ & $81.9 \pm 15.9$ & $86.1 \pm 12.0$ \\
\hline
\end{tabular}


$\mathrm{C} / \mathrm{N}$ values of $\mathrm{C}$. gigas stay quite constant around 4 even in August, when glycogen contents dropped drastically. This supports the above-mentioned accumulation of lipids and the suggested conversion of carbohydrates to lipids during gametogenesis. In both species a clear decrease of the $\mathrm{C}: \mathrm{N}$ ratios was observed after August, when lower values of 3.2 (O. edulis) and 2.5 (C. gigas) indicate the build-up of muscular mass (proteins). These low $\mathrm{C} / \mathrm{N}$ values reflect decreasing lipid and glycogen levels in the bivalves, due to the utilization of these reserves in autumn, when food supply is limited.

Seasonal variations in lipid class compositions of offshore-cultivated oysters are basically similar to those of near-shore-grown individuals (e.g. Abad et al., 1995; De la Parra et al., 2005; Linehan et al., 1999). Within the lipid classes, TAG and WE are the principal energy reserves of most marine invertebrates (Lee et al., 2006). Energy reserves of 0 . edulis and C. gigas are primarily made up of the NL TAG, as WE are not common in oysters (Ackman, 1989). Since gas chromatographic analyses combined with mass spectrometry revealed two fatty alcohols we assume that these wax ester moieties originate from small zooplankton specimens ingested by the oysters. WE and SE are not separated by the applied analytical method (Iatroscan). SE have no energy storage functions but provide important components of membrane lipids (Fraser et al., 1985). We assume that the WE/SE fraction is SE-dominated (e.g. Abad et al., 1995; Ackman, 1989) hence, this fraction will not be of major importance for energy storage processes in the oysters. Still, a certain increase of WE/SE in O. edulis and C. gigas during summer and a subsequent decrease in autumn may point to limited seasonal wax ester storage.

TAGs serve as short-term energy reserves and they are the main lipid stores in oysters. Together with glycogen, they accumulate during periods of high food availability and are depleted in periods of food paucity. Accordingly, the amount of TAGs is a sensitive indicator of the nutritional condition of an animal (Fraser et al., 1985). It can be expressed as the ratio of PL to TAG (PL:TAG) or as the ratio of PL to NL (PL:NL) (Abad et al., 1995; Caers et al., 2000; Watanabe and Ackman, 1974). Values $\leq 1$ indicate a good nutritional state and have been observed e.g. in well-fed adults of 0 . edulis and Crassostrea virginica from the wild (Abad et al., 1995; Watanabe and Ackman, 1974). According to this scale, the European and Pacific oysters of the present study showed poor nutritional conditions at the beginning of the experiment in spring (PL:TAG ratios of 3 (O. edulis) and 18 (C. gigas) respectively). During summer O. edulis fed continuously (Pogoda et al., 2011) and PL and TAG levels reached equal proportions of 1 in summer and in autumn, which indicates a good nutritive state. C. gigas also clearly improved its condition during summer (PL:TAG ratios of about 1). In contrast to $O$. edulis the condition of $C$. gigas significantly deteriorated in autumn reaching a PL:TAG ratio of about 2. These differences in the seasonal TAG accumulation may again be explained by the onset of reproductive activities in $C$. gigas, which was not the case in 0 . edulis (e.g. Newkirk et al., 1995; Royer et al., 2008).

The FA compositions of European and Pacific oysters were dominated by 16:0, 20:5 $(n-3)$ and 22:6(n-3). These are major components of PL and typical of marine organisms (e.g. Lee et al., 2006). The polyunsaturated FA 20:5(n-3) and 22:6(n-3) are important and conservative elements of bio-membranes. Their concentrations remain rather constant and, thus, they are not suitable as direct indicators for the nutritional condition. However, the proportion of PL $(n-6)$ FA, principally 20:4(n-6), can indirectly show the depletion or accumulation of lipid reserves through an increase or decrease, respectively (Child and Laing, 1998). Both species of offshore-cultivated oysters showed a significant decrease $(p<0.001)$ in 20:4(n -6$)$ during high food availability from spring to early summer and therefore indicate the accumulation of lipids as energy reserves.

The amount of essential FA can greatly affect growth and condition of oysters (Pazos et al., 1996) and may serve as an indicator for the preferred diet (Dalsgaard et al., 2003; Soudant et al., 1999). Diatoms, for example, are characterized by high concentrations of 16:1(n-7),
18:1( $\mathrm{n}-7)$ and 20:5(n - 3) FA (Sargent et al., 1987). Dinoflagellates show high amounts of 18:4(n-3), 22:6(n-3) (Sargent et al., 1987; Virtue et al., 1993) and 18:5(n-3) (Mayzaud et al., 1976). In the present study, levels of 22:6(n - 3) stayed quite constant in 0 . edulis, but showed a slight decrease in C. gigas. Furthermore, 18:4( $n-3)$ and 18:5(n-3) were not present or showed very low concentrations, indicating that dinoflagellates were not an important food organism. However, diatom markers increased during spring and early summer in both oyster species and indicated a diet rich in diatoms. During the cultivation experiment, $O$. edulis and $C$. gigas maintained high ratios of $(n-3) /(n-6)$. These increased from 10 to $>18$ in late summer, which furthermore indicates the excellent physiological condition of both oyster species at the offshore site (Pazos et al., 1996; Sargent et al., 1990; Soudant et al., 1999).

Dienoic FA, also known as non-methylene-interrupted FA (NMI FA), in which more than two methylene residues separate the double bonds, are found in a wide range of marine invertebrates, but especially in molluscs. The most common of these FA are 22:2 $\Delta 7,13$ and 22:2 $\Delta 7,15$ and their precursors $22: 2 \Delta 5,11$ and 22:2 $\Delta 5,13$. They are synthesized de novo in bivalves by chain elongation, followed by $\Delta 5$ desaturation of 18:1(n - 9) and 16:1(n-7), respectively (Barnathan, 2009). Offshore-cultivated oysters of this study showed two newly synthesized NMI FA (22:2 $\Delta 7,13$ and 22:2 $\Delta 7,15)$ in similar concentrations as near-shore-grown oysters (Abad et al., 1995; Pazos et al., 1996; Soudant et al., 1999). Apparently, the nutritional situation at the offshore site and especially levels of 16:1(n-7) were high enough to allow biosynthesis of these FA (Soudant et al., 1999; Thompson and Harrison, 1992; Zhukova, 1991).

\section{Summary and conclusions}

(1) Offshore-cultivated oysters generally exhibited excellent physiological conditions during the growing season, as indicated by their proximate biochemical compositions (protein, glycogen and lipid contents) as well as TAG and FA profiles.

(2) Both species accumulated glycogen in periods of high food availability.

(3) We postulate that $C$. gigas started to invest energy in maturation in summer, which resulted in low glycogen values and TAG accumulation until autumn. In contrast, $O$. edulis of the same age and size showed no reproductive activities and continued accumulation of glycogen until autumn and showed a constant TAG increase, also in autumn.

(4) O. edulis and C. gigas are suitable candidates for offshore aquaculture operations, even if they would only be transferred during the summer season for grow-out.

\section{Outlook}

Modern concepts for offshore aquaculture rely on sustainable and environmentally friendly cultivation techniques combined with economic viability. Integrated multi-trophic aquaculture (IMTA) reduces eutrophication problems (Troell et al., 2009) and strives for a balanced budget of nutrient input and uptake. Filter-feeding oysters are therefore an ideal bio-extractive component for the realization of IMTA in offshore areas. The rapid development of wind farming projects in many offshore areas of the world (Breton and Moe, 2009; OWE, 2012) offers the opportunity of parallel utilization for offshore aquaculture operations and financial benefits of such a "multi-use". Today, sharing of e.g. windmill groundings to attach culture cages, as well as combined maintenance vessels are being discussed and established (Buck et al., 2008). Correspondingly, this study clearly qualified both, the European oyster and the Pacific oyster, as suitable candidates for such offshore aquaculture operations. 


\section{Acknowledgements}

We thank the Water and Shipping Authority Bremerhaven as well as the Water and Shipping Authority Wilhelmshaven, namely $\mathrm{Mr}$ Boening and the captains and crews of MV Bruno Illing and MV Mellum, for their support in maintaining the test site Nordergründe. Thanks are expressed to the captain and crew of the AWI research vessel Uthörn for their assistance. We also thank all divers involved in this project and the AWI diving group for their technical support. Thanks go to Dr. Martin Graeve (AWI) who confirmed fatty acid identifications by mass spectrometry. All research carried out for this manuscript was funded by the University of Bremen and the Alfred Wegener Institute for Polar and Marine Research and is further a partial fulfillment for a doctoral degree of the leading author.

\section{References}

Abad, M., Ruiz, C., Martinez, D., Mosquera, G., Sánchez, J.L., 1995. Seasonal variations of lipid classes and fatty acids in flat oyster, Ostrea edulis, from San Cibran (Galicia, Spain). Comparative Biochemistry and Physiology 110 (2), 109-118.

Ackman, R.G., 1989. Marine Biogenic Lipids, Fats and Oils., I-II. CRC Press, Boca Raton, Florida, USA (496 pp.).

Barnathan, G., 2009. Non-methylene-interrupted fatty acids from marine invertebrates: occurrence, characterization and biological properties. Biochimie 91, 671-678.

Bayne, B.L., 2009. Carbon and nitrogen relationships in the feeding and growth of the Pacific oyster, Crassostrea gigas (Thunberg). Journal of Experimental Marine Biology and Ecology 374, 19-30.

Beninger, P.G., Lucas, A., 1984. Seasonal variations in condition, reproductive activity, and gross biochemical composition of two species of adult clam reared in a common habitat: Tapes decussates L. (Jeffreys) and Tapes philippinarum (Adams \& Reeve). Journal of Experimental Marine Biology and Ecology 79, 19-37.

Brenner, M., 2009. Site selection criteria and technical requirements for the offshore cultivation of Blue mussels (Mytilus edulis L.). PhD Thesis, Jacobs University Bremen, Germany, $152 \mathrm{pp}$.

Breton, S.P., Moe, G., 2009. Status, plans and technologies for offshore wind turbines in Europe and North America. Renewable Energy 34, 646-654.

BSH, 2006. Marine Environmental Database (MUDAB). Bundesamt für Seeschifffahrt und Hydrographie (BSH), Hamburg, Germany.

$\mathrm{BSH}, 2009$. Marine environment reporting system information for the North Sea and Baltic Sea (MURSYS). Bundesamt für Seeschifffahrt und Hydrographie (BSH), Hamburg Germany (Online data acquisition http://www.bsh.de Accessed November 2010).

Buck, B.H., 2002. Open ocean aquaculture und Offshore-Windparks: Eine Machbarkeitsstudie über die multifunktionale Nutzung von Offshore-Windparks und Offshore Marikultur im Raum Nordsee. Reports on Polar and Marine Research, Bremerhaven 412, 1-252.

Buck, B.H., 2007. Experimental trials on the feasibility of offshore seed production of the mussel Mytilus edulis in the German Bight: installation, technical requirements and environmental conditions. Helgoland Marine Research 61, 87-101.

Buck, B.H., Krause, G., Rosenthal, H., 2004. Extensive open ocean aquaculture development within wind farms in Germany: the prospect of offshore co-management and legal constraints. Ocean and Coastal Management 47 (3-4), 95-122.

Buck, B.H., Krause, G., Michler-Cieluch, T., Brenner, M., Buchholz, C.M., Busch, J.A., Fisch, R., Geisen, M., Zielinski, O., 2008. Meeting the quest for spatial efficiency: progress and prospects of extensive aquaculture within offshore wind farms. Helgoland Marine Research 62, 269-281.

Caers, M., Coutteau, P., Sorgeloos, P., 2000. Impact of starvation and of feeding algal and artificial diets on the lipid content and composition of juvenile oyster (Crassostrea gigas) and clams (Tapes philippinarum). Marine Biology 136, 891-899.

Child, A.R. Laing, I., 1998. Comparative low temperature tolerance of small juvenile European, Ostrea edulis L., and Pacific oysters, Crassostrea gigas Thunberg. Aquaculture Research 29, 103-113.

Costil, K., Royer, J., Ropert, M., Soletchnik, P., Mathieu, M., 2005. Spatio-temporal variations in biological performances and summer mortality of the Pacific oyste Crassostrea gigas in Normandy (France). Helgoland Marine Research 59, 286-300.

Dalsgaard, J., St John, M., Kattner, G., Muller-Navarra, D., Hagen, W., 2003. Fatty acid trophic markers in the pelagic marine environment. Advances in Marine Biology 46, 225-340.

De la Parra, A.M., García, O., Fuencisla, S.J., 2005. Seasonal variation on the biochemical composition and lipid classes of the gonadal and storage tissues of Crassostrea gigas (Thunberg, 1794) in relation to the gametogenic cycle. Journal of Shellfish Research 24 (2), 457-467.

Delmendo, M.N., 1998. Bivalve farming: an alternative economic activity for small-scale coastal fishermen in the ASEAN region. ASEAN/UNDP/FAO Regional Small-Scale Coastal Fisheries Development Project, Manila, Philippines (43 pp.).

Dridi, S., Romdhane, M.S., Elcafsi, M., 2007. Seasonal variation in weight and biochemical composition of the Pacific oyster, Crassostrea gigas in relation to the gametogenic cycle and environmental conditions of the Bizert lagoon, Tunisia. Aquaculture 263 238-248.

FAO, 2009. The State of World Fisheries and Aquaculture - 2008 (SOFIA). FAO Fisheries and Aquaculture Department (176 pp.).

FAO, 2011. Fisheries and Aquaculture Information and Statistics Service. www.fao.org/ fishery/aquaculture/en (Accessed January 2011).
Ferreira, J.G., Sequeira, A., Hawkins, A.J.S., Newton, A., Nickel, T.D., Pastres, R., Forte, J., Bodoy, A., Bricker, S.B., 2009. Analysis of coastal and offshore aquaculture: Application of the FARM model to multiple systems and shellfish species. Aquaculture 289, $32-41$.

Folch, J., Lees, M., Sloane-Stanley, G.H., 1957. A simple method for isolation and purification of total lipids from animal tissues. Journal of Biological Chemistry 226, 497-509.

Fraser, A.J., Tocher, D.R., Sargent, J.R., 1985. Thin-layer chromatography - flame ionization detection and the quantification of marine neutral lipids and phospholipids. Journal of Experimental Marine Biology and Ecology 88, 91-99.

Gallager, S.M., Mann, R., 1986. Growth and survival of larvae of Mercenaria mercenaria (L.) and Crassostrea virginica (Gmelin) relative to broodstock conditioning and lipid content of eggs. Aquaculture 56, 105-121.

Garen, P., Robert, S., Bougrier, S., 2004. Comparison of growth of mussel, Mytilus edulis, on longline, pole and bottom culture sites in the Peruis Breton, France. Aquaculture 232, $511-524$

Gibbs, M.T., 2004. Interactions between bivalve shellfish farms and fishery resources. Aquaculture 240, 267-296.

Hagen, W., 2000. Lipids. In: Harris, R.P., Wiebe, P.H., Lenz, J., Skjoldal, H.R., Huntley, M. (Eds.), ICES Zooplankton Methodology Manual. Academic Press, London, pp. 113-119.

Holland, D.L., Hannant, P.J., 1974. Biochemical changes during growth of the spat of the oyster, Ostrea edulis. Journal of the Marine Biological Association of the United Kingdom 54 (4), 1007-1016.

Hummel, H., De Wolf, L., Zurburg, W., Apon, L., Bogaards, R.H., Van Ruitenburg, M., 1989. The glycogen content in stressed marine bivalves: the initial absence of a decrease. Comparative Biochemistry and Physiology 94B (4), 729-733.

Kattner, G., Fricke, H.S.G., 1986. Simple gas-liquid chromatography method for simultaneous determination of fatty acids and alcohols in wax esters of marine organisms. Journal of Chromatography 361, 263-268.

Keppler, D., Decker, K., 1984. In: Bergmeier, H.U. (Ed.), Glycogen. : Methods of Enzymatic Analysis, VI. Verlag Chemie, Weinheim, pp. 11-18.

Krause, G., Buck, B.H., Rosenthal, H., 2003. Multifunctional use and environmental regulations: potential in the offshore aquaculture development in Germany. Proceedings of the Multidisciplinary Scientific Conference on Sustainable Coastal Zone Management "Rights and Duties in the Coastal Zone", 12-14 June 2003, Stockholm, Sweden (6 pp.).

Kunst, A., Draeger, B., Ziegenhorn, J., 1984. D-glucose. In: Bergmeier, H.U. (Ed.), UVmethod with hexokinase and glucose-6-phosphate dehydrogenase. : Methods of Enzymatic Analysis, VI. Verlag Chemie, Weinheim, pp. 163-172.

Lee, R.F., Hagen, W., Kattner, G., 2006. Lipid storage in marine zooplankton. Marine Ecology Progress Series 307, 273-306.

Li, Y., Qin, J.G., Li, X., Benkendorff, K., 2009. Monthly variation of condition index, energy reserves and antibacterial activity in Pacific oysters, Crassostrea gigas, in Stansbury (South Australia). Aquaculture 286, 64-71.

Linehan, L.G., O'Connor, T.P., Burnell, G., 1999. Seasonal variation in the chemical composition and fatty acid profile of Pacific oysters (Crassostrea gigas). Food Chemistry 64, 211-214.

Løfstedt, M.B., 2010. The effect of food quality on glycogen content, the fatty acid profile and winter mortality in cultivated oyster spat (Ostrea edulis). Aquaculture Nutrition 16, 625-636

Lowry, O.H., Rosebrough, N.J., Farr, A.L., Randall, R.J., 1951. Protein measurement with the Folin phenol reagent. Journal of Biological Chemistry 193, 265-275.

Matthiessen, G.C., 2001. Oyster Culture. Fishing News Books, London, England (163 pp.).

Mayzaud, P., Eaton, C.A., Ackman, R.G., 1976. The occurrence and distribution of octadecapentaenoic acid in a natural plankton population. A possible food chain index. Lipids 11, 858-862.

McElwee, J., 1998. The sociological and environmental impacts of open ocean aquaculture. In: Stickney, R.R. (Ed.), Joining Forces with Industry - Open Ocean Aquaculture: Proceedings of the Third Annual International Conference 10-15 May 1998, Corpus Christi, Texas Sea Grant College Program, pp. 31-35.

Newkirk, G.F., Muise, B., Enright, C.T., 1995. Culture of the Belon oyster, Ostrea edulis, in Nova Scotia. In: Boghen, A.D. (Ed.), Cold-Water Aquaculture in Atlantic Canada. Canadian Institute for Research on Regional Development, pp. 225-253.

OWE, 2012. Offshore Wind Energy Europe. viewed 17 Feb 2012. http://www. offshorewindenergy.org.

Pazos, A.J., Ruíz, C., García-Martín, O., Abad, M., Sánchez, J.L., 1996. Seasonal variations of the lipid content and fattyacid composition of Crassostrea gigas cultured in El Grove, Galicia, N.W. Spain. Comparative Biochemistry and Physiology 114B (2), 171-179.

Pogoda, B., Buck, B.H., Hagen, W., 2011. Growth performance and condition of oysters (Crassostrea gigas and Ostrea edulis) farmed in an offshore environment (North Sea, Germany). Aquaculture 319, 484-492.

Postel, L., Fock, H., Hagen, W., 2000. Biomass and abundance. In: Harris, R.P., Wiebe, P.H., Lenz, J., Skjoldal, H.R., Huntley, M. (Eds.), ICES Zooplankton Methodology Manual. Academic Press, London, pp. 83-192.

Robert, R., Trut, G., Borel, M., Maurer, D., 1993. Growth, fatness and gross biochemical composition of the Japanese oyster, Crassostrea gigas, in Stanway cylinders in the Bay of Arcachon, France. Aquaculture 110 (3-4), 249-261.

Robinson, A., 1992. Dietary supplements for the reproductive conditioning of Crassostrea gigas kumamoto (Thunberg): II: Effects on glycogen, lipid and fatty acid content of broodstock oysters and eggs. Journal of Shellfish Research 11 (2), 443-447.

Rose, J.M., Tedesco, M., Wikfors, G.H., Yarish, C., 2010. International Workshop on Bioextractive Technologies for Nutrient Remediation Summary Report International Workshop on Bioextractive Technologies for Nutrient Remediation: Dec 3-4, 2009, University of Connecticut, Stamford, U.S.A. National Oceanic and Atmospheric Administration (NOAA), Northeast Fisheries Science Center Reference Document, pp. 10-19 (18 pp.). 
Royer, J., Seguineau, C., Park, K.I., Pouvreau, S., Choi, K.S., Costil, K., 2008. Gametogenetic cycle and reproductive effort assessed by two methods in 3 age classes of Pacific oysters, Crassostrea gigas, reared in Normandy. Aquaculture 277, 313-320.

Ruíz, C., Martinez, D., Mosquera, G., Abad, M., Sánchez, J.L., 1992. Seasonal variations in condition, reproductive activity and biochemical composition of the flat oyster, Ostrea edulis, from San Cibran (Galicia, Spain). Marine Biology 112, 67-74.

Ryan, J., 2005. Offshore Aquaculture - Do we need it, and why is it taking so long? Expert workshop on "Sustainable Aquaculture. : DG JRC European Commission, Institute for Prospective Technological Studies, 17-18 Jan 2005, Seville, Spain. International Salmon Farmers Association, Ireland.

Saborowski, R., Buchholz, F., 1996. Annual changes in the nutritive state of North Sea dab. Journal of Fish Biology 49, 173-194.

Sargent, J.R., Parkes, J.R., Mueller-Harvey, I., Henderson, R.J., 1987. Lipid biomarkers in marine ecology. In: Sleigh, M.A. (Ed.), Microbes in the Sea. Ellis Horwood, Chichester, pp. 119-138.

Sargent, J.R., Bell, M.V., Henderson, R.J., Tocher, D.R., 1990. In: Mellinger, J. (Ed.), Polyunsaturated fatty acids in marine and terrestrial food webs. : Animal nutrition and transport processes, 5. Karger, Basel, pp. 11-22.

Schmidt-Nielsen, K., 1999. Physiologie der Tiere. Spektrum Akademischer Verlag, Heidelberg/Berlin, pp. 146-147.

Soletchnik, P., Faury, N., Goulletquer, P., 2006. Seasonal changes in carbohydrate metabolism and its relationship with summer mortality of the Pacific oyster Crassostrea gigas (Thunberg) in Marennes-Oléron Bay (France). Aquaculture 252, 328-338.

Soudant, P., Van Ryckeghem, K., Marty, Y., Moal, J., Samain, J.F., Sorgeloos, P., 1999. Comparison of the lipid class and fatty acid composition between a reproductive cycle in nature and a standard hatchery conditioning of the Pacific oyster Crassostrea gigas. Comparative Biochemistry and Physiology 123 (2), 209-222.

Takayanagi, K., 1998. Water quality guidelines for aquaculture: an example in Japan. In: Howell, W.H., Keller, B.J., Park, P.K., McVey, J.P., Takayanagi, K., Uekita, Y. (Eds.), Nutrition and Technical Development of Aquaculture: Proceedings of the 26th US-
Japan Aquaculture Symposium, Durham/New Hampshire/U.S.A. September 16-18, 1997. UJNR Technical Report No. 26, Durham, University of New Hampshire Sea Grant Program, pp. 247-254.

Thompson, P.A., Harrison, P.J., 1992. Effects of monospecific algal diets of varying biochemical composition on the growth and survival of Pacific oyster (Crassostrea gigas). Marine Biology 113, 645-654.

Troell, M., Joyce, A., Chopin, T., Neori, A., Buschmann, A.H., Fang, J.G., 2009. Ecological engineering in aquaculture - potential for integrated multi-trophic aquaculture (IMTA) in marine offshore systems. Aquaculture 297, 1-9.

Virtue, P., Nichols, P.D., Nicol, S., McMinn, A., Sikes, E.L., 1993. The lipid composition of Euphausia superba Dana in relation to the nutritional value of Phaeocystis pouchetii (Hariot) Lagerheim. Antarctic Science 5, 169-177.

Walne, P.R., 1974. Culture of bivalve molluscs: 50 years experience at Conwy. Fishing News Books, London, England (173 pp.).

Watanabe, T., Ackman, R.G., 1974. Lipids and fatty acids of the American (Crassostrea virginica) and European flat (Ostrea edulis) oysters from a common habitat and after one feeding with Dicrateria inornata and Isochrysis galbana. Journal of the Fisheries Research Board of Canada 31, 403-409.

Whyte, J.N.C., Englar, J.R., Carswell, B.L., 1990. Biochemical composition and energy reserves in Crassostrea gigas exposed to different levels of nutrition. Aquaculture 90, 157-172.

Wilson, J.H., Simons, L., 1985. Gametogenesis and breeding of Ostrea edulis on the west coast of Ireland. Aquaculture 46, 307-321.

Wirtz, K., Tol, R., Hooss, G., 2002. Mythos “Offene See”: Nutzungskonflikte im Meeresraum. In: Lozán, J., Rachor, E., Reise, K., Sündermann, J., Westernhagen, H.V. (Eds.), Warnsignale aus Nordsee \& Wattenmeer: Eine aktuelle Umweltbilanz. Wissenschaftliche Auswertungen, Hamburg, pp. 157-160.

Zhukova, N.V., 1991. The pathway of the biosynthesis of non-methylene-interrupted dienoic fatty acids in molluscs. Comparative Biochemistry and Physiology B 100, 801-804 